\title{
PATRYSTYKA W CZASOPISMACH 2000 ROKU
}

1. ACTA MEDIAEVALIA 12 (1999):

S. Bafia - Nauka Teodoryka z Chartres o jedności Boga w Trójcy Świętej w komentarzu do "Opuscula Sacra» Boecjusza 65-97.

2. ACTA PHILOSOPHICA 9 (2000) nr 1-2:

D. Gammara - Uno caso di platonismo ed agostinismo medievale. Matteo d'Acquasparta: conoscenza ed esistenza 197-221.

3. ACTA UNIVERSITATIS LODZIENSIS. FOLIA HISTORICA (2000) nr 67-68:

(Nr 67) S. Bralewski - Wątki polityczne w oskarżeniach kierowanych przeciwko biskupom w późnym cesarstwie rzymskim 7-22; T. Wolińska - Zwiąki rodzinne w polityce personalnej Justyniana I, 23-44; M.J. Leszka - Zbrodnie Cesarza Fokasa 45-58; M. Kokoszko - Kanon portretowania w historiografii bizantyńskiej na przyktadzie portretu Boemunda $w$ „Aleksjadzie” Anny Komneny 59-73.

4. ACTA UNIVERSITATIS PALACKIANAE OLOMUCENSIS 1 (1999):

E. Sotoniaková - Basileias: Die Hilfe an die Bediurftigen. Sozialer Aspekt der Lehre des hl. Basilios des Grossen vom Eigentum, s. 7 (1-13).

5. ACTA UNIVERSITATIS WRATISLAVIENSIS (2000) nr 37 (Filozofia): J. Zieliński - Źródta filozofii wczesnochrześcijańskiej - stoicyzm 13-32; M. Manikowski - Niepoznawalny Bóg w teofanii Księgi Wyjścia 33-52; D. Dembińska-Siury - Chrześcijaństwo, hellenizm i tradycja grecka w IV wieku 53-81; A. Świtkiewicz-Blandzi - Uwagi dotyczace wptywu Pseudo-Dionizego w Kościele Wschodnim (VI-XIV w.) 83-93; K. Szlachcic - Chrześcijaństwo, „conditio sine qua non” nauki Zachodu 95-105.

6. AEVUM 74 (2000) nr 1-3:

C. Minelli - La data dell' «Apologeticum» di Tertulliano 185-189; L.F. Pizzolato - Ambrogio "grammaticus” 207-222; S. Fazzo - La versione araba del

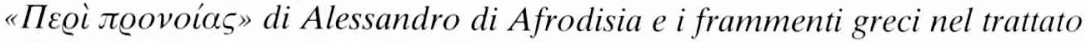
"Contra Iulianum» di Cirillo Alessandrino 309-419; L. Pasini - Resti della "Catena sui Proverbi» di Procopio di Gaza in un frammento pergamenaceo 
nel Codice Ambrosiano B 85 sup. 421-429; R.G. Babcock - Angelomus and Manuscripts from the Luxeuil Library 431-440; G. Baroffio - „Iter Liturgicum Ambrosianum". Inventario sommario di libri liturgici ambrosiani 583-603.

7. THE AMERICAN BENEDICTINE REVIEW 51 (2000) nr 1-4:

E. Hollerman - Humility in The Rule of Benedict: A Theological and Historical Analysis of Nineteenth and Twentieth Century Interpretations 254-281; C.J. Peifer - The Origins of Benedictine Monasticism: State of the Question 293-315; ( $\mathrm{nr} 4) 50$ Year Index (Monasticism, Literature, Spirituality, Theology, Philosophy, History, Miscellaneous) 1-176.

8. AMERICAN CATHOLIC PHILOSOPHICAL QUARTERLY 74 (2000) nr 1-4:

M.T. Clark - Augustine on Immutability and Mutability 7-27; R.J. Teske The Heaven of Heaven and the Unity of St. Augustine's "Confessions» 2945; D.V. Meconi - „Grata Sacris Angelis”: Gender and the „Imago Dei” in Augustine's «De Trinitate» XIII, 47-62; D.X. Burt - Friendly Persuasion: Augustine on Religious Toleration 63-76; D. Kries - Augustine's Response to the Political Critics of Christianity in the "De Civitate Dei» 77-93; J. Rist What Will I Be Like Tomorrow? Augustine versus Hume 95-114; J. WetzelCrisis Mentalites: Augustine after Descartes 115-133; J.K.A. Smith - How (Not) To Tell a Secret: Interiority and the Strategy of "Confessions" 135-151; C.A.J. Coady - J. Ross - St. Augustine and the Ideal of Peace 153-161.

9. ANALECTA BOLLANDIANA 117 (1999) nr 1-4:

R.W. Burgess - The Dates of the Martyrdom of Simeon bar Sabba'e and the Great Massacre 9-47; R. Mercier - The Dates in Syriac Martyr Acts 47-66; E. Lucchesi - Le dossier d'apa Zénobe. Addenda et corrigenda 67-72; Une catéchèse de Chenouté sur la Résurection contre les origénistes 73-76; Un „logos” inconnu d'Isaïe de Scété: Chenouté, Isaïe et Moïse 76-80; U. Zanetti - Un témoin slave complétant la Vie de S. Théodote de Cyrénie (BHG 2434), 81-88; S.J. Shoemaker - The Sahidic Coptic Homily on the Dormition of the Virgin Attributed to Evodius of Rome. An Edition from Morgan Manuscripts 596 and 598 with Translation 241-283; E. Lucchesi - Evagrius Copticus 284; Pierre l'Apôtre et Pierre d'Alexandrie 285-288; L'homélie copte acéphale en l'honneur des XXIV Vieillards 289-290; J. Noret - La rédaction de la «Disputatio cum Pyrrho» (CPG 7698) de saint Maxime Confesseur seraitelle postérieure à 655?, 291-296; J. Van Der Straeten - Catalogues de manuscrits latins: inventaire hagiographique (22 série) 394-419.

10. ANALECTA BOLLANDIANA 118 (2000) nr 1-4:

F.J. Thomson - The Slavonic translation of the hitherto untraced Greek "Homilia in nativitatem Domini nostri Jesu Christi" by Atticus of Constantinople 5-36; J. Noret - À qui était destinée la Lettre BHG 1233d d'Anastase l'Apocrisiaire? 37-42; Th. Gärtner - Zwei Textvorschläge zur metrischen 
Eustathiusvita (BHL 2768), 43-46; J.L. Feiertag - À propos du rôle des Juifs dans les traditions sous-jacentes aux récits de l'Invention de la Croix 241-165; E. Lucchesi - Des "Actes des Apôtres» au «Martyre de Pierre d'Alexandrie» 266; T. Satoshi - La Vie de S. Macaire l'Égyptien 267-290; J. Van Der Straeten - Catalogues de manuscrits latins. Inventaire hagiographique (Vingt-troisième série) 399-440.

11. ANALECTA CRACOVIENSIA 32 (2000):

S. Stabryła - „Christiani nominis hostis”: Images of the Persecutors of Christians in Prudentius' «Peristephanon» 381-390.

12. ANALES DE LA FACULTAD DE TEOLOGÍA 51(2000) nr 2 (Sapientia Patrum):

R. Fermandois Polanko - La encarnación en la teología de San Ireneo de Lyon 43-89; A.E. Edwards - Carne plasmada a imagen y semejanza del Verbo, según San Ireneo 91-102; A.L. Capboscq - Filosofía y Teología en la escuela de Orígenes. Notas sobre un pasaje del Panegírico de Gregorio Taumaturgo 103-116; F. Cocchini - Osservazioni su alcuni brani dal 1.2 del «Commentario al Cantico dei Cantici» di Origene 117-133; S.E. Fernández - „A manifestis, ad occulta”. Las realidades visibles como único camino hacia las invisibles en el «Comentario al Cantar de los Cantares» de Orígenes 135-159; A.F. Castellano - Amor, Sabiduría y Ciencia en el «Comentario al Cantar de los Cantares» de Orígenes 161-182; C.L. Sotomayor - Sobre el hijo perfecto en Hilario de Poitiers 185-198; A.W. Meis - Basilio, De Spiritu Sancto? El significado pneumatológico de Koıvwvía 199-224; C. Pierantoni - Reflexiones sobre el ,incipit” de las «Confesiones» 225-234; O. Velásquez - Los conceptos de ciudad celeste y ciudad terrena en el «De Civitate Dei» de San Agustín 235-252; C.I.R. Casale - La „Actualidad” de la Tradición. A propósito de la teología, de Máximo el Confesor, del hijo de Dios como hombre 253-269; M.T.R. Viviani - Arquitectura y dogma en Anatolia. Arrianos y Capadocios (siglos IV d.c. - VI d.c.) 271-294.

13. ANAMNESIS 6 (1999/2000) nr 21-23:

(Nr 21) T.M. Dąbek - Czytania biblijne, patrystyczne $i$ hagiograficzne w Liturgii Godzin 118-129.

14. ANGELICUM 77 (2000) nr 1-4:

W. Dąbrowski - Il concetto della Rivelazione nel «Super Boetium De Trinitate» di san Tommaso d'Aquino 459-475.

15. ANNALES THEOLOGICI 14 (2000) nr 1-2:

M. Tábet - I preludi in epoca patristica dei moderni trattati sulla natura e l'interpretazione della Bibbia 45-78; B. Estrada - L'Eucaristia nella vita della primitiva comunità cristiana. A proposito di At 2, 42-47, 81-101.

16. ANNALI DI STORIA DELL' ESEGESI 17 (2000) nr 1-2:

(Nr 1) J.N. Guinot - Eschatologie et Écriture en milieu antiochien à partir du II siècle 9-46; P. Siniscalo - L'Escatologia di Tertulliano: tra Rivelazione 
scritturale e dati razionali, "psicologici», naturali 73-89; E. Prinzivalli L'incidenza della problematica escatologica nella controversia origenista fra III e IV secolo 91-107; A. Pollastri - Escatologia e Scrittura nell'Ambrosiaster 109-132, M. Pia Ciccarese - La nascita del purgatorio 133-150; G. Lusini - Riflessi etiopici dell'escatologia di Afraate 151-159; L.F. Pizzolato - L'antitipo: un concetto tra esegesi e mistagogia 161-202.

18. ANNUARIUM HISTORIAE CONCILIORUM 32 (2000) nr 1-2:

P. Brums - Bemerkungen zur Rezeption des Nicaenums in der ostsyrischen Kirche 1-22; A. García y García - La Ecumenicidad de los Concilios Generales de la Edad Media 44-60.

19. ANTIQUITAS 25 (2000):

A. Wypustek - Accusations portées contre les chrétiens aux II et III siècles pour détention de livres de magie. Quelques remarques dans la lignée du livre de W. Speyer 179-190.

20. ANUARIO DE HISTORIA DE LA IGLESIA 9 (2000):

R. Trevijano Etcheverría - La diffusion de la Iglesia en el área mediterránea hasta la paz constantiniana 31-46; D. Ramos-Lissón - El proceso evangelizador del norte de África desde la época constantiniana hasta la invasión islámica 47-67; J. Orlandis - Le doble conversion religiosa de los pueblos germánicos (siglos IV a VIII) 69-84; V. Peri - La cristianizzazione delle etnie slave (secoli VII-XI) 85-108.

21. ANUARIO FILOSOFICO 33 (2000) nr 1-2:

J. de Garay - La extrańeza de la inteligencia en Filón de Alejandría 203-216; J.A. Aersten - Filosofía cristiana: primacía del ser „versus” primacía del bien 339-361; Y. de Andía - Neoplatonismo y cristianismo en PseodoDionisio Areopagita 363-394; G. Ceresola - Resonancias neoplatónicas en la condena agustiniana de la fantasía 583-592; P. Faitanin - La huella de la

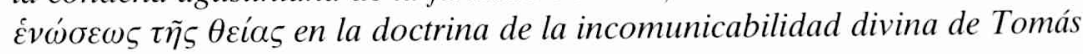
de Aquino 593-605.

22. AQUINAS 43 (2000) nr 1-2:

G. Santi - Il problema del male e la sua redenzione. Un dibattito su Agostino 159-167.

26. ARCHIV FÜR RELIGIONSGESCHICHTE 2 (2000) nr 1-2:

D. Frankfurter - The Consequences of Hellenism in Late Antique Egypt: Religions Worlds and Actor 162-194; F. Dolbean - Un opuscule latin contre les Manichéens, placé sous le nom d'Augustin 232-254.

27. ARCHIWUM HISTORII FILOZOFII I MYŚLI SPOŁECZNEJ 45 (2000):

A. Świtkiewicz-Blandzi-Dzieje filozoficznego i teologicznego sporu wokót doktryny św. Grzegorza Palamasa na tle relacji państwo - Kościót w XIVwiecznym Bizancjum 103-115.

28. ATENEUM KAPŁAŃSKIE (2000) t. 134-135, z. 545-550: 
(z. 549-550) A. Swoboda - Godność męża w pismach Plutarcha z Cheronei i autorów chrześcijańskich IV w. (Augustyn, Ambroży, Hieronim) 286-298.

29. ATHENAEUM 18 (2000) nr 1-2:

G. D'Anna - A proposito di una recente edizione degli «Additamenta» di Girolamo ai «Chronica» di Eusebio 547-558; J.Tantillo - Filostorgio e la tradizione sul testamento di Constantino 559-563; M. Francesio - A proposito di un passo dell" "Antiochikos» di Libanio 580-584.

30. AUGUSTINIANUM 40 (2000) nr 1-2:

M.G. Mara - Nota sulle ragioni della carità nell'antichità cristiana 5-19; A. Stewart-Sykes - «Vita Polycarpi»: an Ante-Nicene Vita 21-33; B. de Margerie - Insinuations trinitaires dans le Psaume 33(32), 6 chez les Pères de l'Église et notamment chez saint Basile 35-41; J.R. Pouchet - Les letters christologiques de Grégoire de Nazianze à Clédonios. De la lettre 102 à la lettre 101, 43-58; S.J. Voicu - Crisostomo, In Psalmum 104 (CPG 4413, 4): una citazione dimenticata 59-63; K.E. Borresen - Gender and Exegesis in the Latin Fathers 65-76; N. Adkin Biblia Pagana: Classical Echoes in the Vulgate 77-87; W. Dunphy - The Lost Manuscript of Pseudo-Rufinus: "De fide» 89-103; R. Wiśniewski - „Bestiae Christum loquuntur” ou des habitants du désert et de la ville dans la "Vita Pauli» de saint Jérôme 105-144; J.N. Guinot - L'exégèse ambrosienne des apparitions pascales (Lc. 24) 145-172; A. Fitzgerald - Ambrose and Augustine: „Confessio” as ,, initium iustitiae” 173-185; R. Dodaro - Note on the Carthaginian Debate over Sinlessness (Augustine, Pecc. mer. 2.7.8-16.25), 187-202; N. Cipriani - Sulla fonte varroniana delle discipline liberali nel «De ordine» di s. Agostino 203-224; G. Fidelibus Grazia e storicità nel disegno del "De civitate Dei»: un percorso di ragione 225-254; S. Dagemark - Funeral as a Hagiographic Motif in «Vita Augustini» and some other Biographies of Bishops 255-289; G. Rapisarda - Continuità tra Antico e Nuovo Testamento in Cromazio di Aquileia 291-302; P. Badot \& D. De Decker - L'apport d'Eucher au développement de l'hagiographie gallo-romaine 303-308.

31. AUGUSTINUS 45 (2000) nr 176-179:

F.B.A. Asiedu - El «Hortensius» de Cicerón, la filosofía y la vida mundana del joven Agustín 5-25; P. Burnell - Las funciones de la familia y de la sociedad civil en «La Ciudad de Dios» de San Agustín 27-33; M.M. ${ }^{\text {a }}$ Campelo - San Agustín y el Padrenuestro 35-89; A. De Silva - Agustín de nuevo 91-102; H.R. Drobner - La cronología de los «Sermones ad populum» de san Agustín 103-108; J. Lössl - „De peccatorum meritis et remissione” y „De spiritu et littera": Su dependencia respecto a «De libero arbitrio» y a «De diuersis quaestionibus ad Simplicianum»109-146; F. Moriones - Jesucristo redentor y maestro de humildad, según san Agustín 147-190; F. Navarro Coma - La correspondencia de Agustín durante su estancia en Casiciaco. Una reconstrucción 191-213; R.C.Jr. Trundle - San Agustín y el Dios del 
filósofo moderno 215-225; AA. VV. - Memoria y homenaje Fr. Eugenio Ayape. Fr. Francisco Moriones 293-326; P. Busquet Tres - Entre la diferencia y la paz. El espacio de la tolerancia en el «De civitate Dei» 327-350; Á. De Silva - Es hoy el pecado original el menos original de los pecados 351-357; E. Eguiarte Bendímez - „Homo Dei”. La figura de Ambrosio como modelo de pastor de la Iglesia, en las "Confesiones» de san Agustín 359-382; E. Gómez - „Homo uiator”. Lugar de la esperanza, en la opción vital agustiniana 383-422; J. Highland - Temor y vergüenza en la conversión de Agustín 423-433; S. Mañero Mañero - San Agustín y la razón ante la pena de daño 435-442; M. Spicer - Génesis 5, 1-32 y el esquema antediluviano en "La ciudad de Dios» 15, de Agustín 443-463.

34. BIBEL UND KIRCHE 55 (2000) nr 1-4:

J. Hartenstein - Maria Magdalena in apokryphen Evangelien 188-191; A. Jensen - Maria von Magdala in den früh- und ostkirchlichen Traditionen 192-194.

35. BIBLICAL RESEARCH 44 (1999):

G.F. Snyder - Sea Monsters in Early Christian Art 7-21; J.A. Kelhoffer Ordinary Christians as Miracle Workers in the New Testament and the Second and Third Century Christian Apologists 23-34.

39. BIELSKO-ŻYWIECKIE STUDIA TEOLOGICZNE 2 (2000):

G. Stephan - Wczesnochrześcijańskie poglądy o poczatkach życia ludzkiego i ich moralne konsekwencje 165-176.

40. BOBOLANUM 11 (2000) nr 1-2:

J. Jurasz - Komentarze do Prz 8, $22 w$ dobie arianizmu - ostatnia faza konfliktu 225-240; W. Chrostowski - Polskie podręczniki archeologii biblijnej $i$ archeologii Palestyny 475-493.

41. BULLETIN DE L'ASSOCIATION GUILLAUME BUDÉ (2000) nr l -4: G. Guillaume-Coirier - Des couronnes virgiliennes pour un „convivium” littéraire (Sidoine Apollinaire, Epist. IX 13, 5, 44-53; B. Petey-Girard Guillaume Budé traducteur de saint Basile: remarques sur les deux traductions de l'épître „, de vita solitaria” 235-246; L. Gosserez - Modernité baudelairienne et „décadence” latine: le poète latin Prudence, une source de Baudelaire? 247-258.

42. BULLETIN DE LITTERATURE ECCLÉSIASTIQUE 101 (2000) nr 1-4: M. Doucet - L',,Ordo expositionis" dans les «Moralia» de saint Grégoire le Grand 99-120; D. Vigne - Bulletin de patristique 181-196; J.P. Weiss - La descente du Christ aux enfers et le thème de la lumière dans les homélies pascales du Pseudo-Eusèbe le Gallican 339-366.

43. BYZANTINISCHE ZEITSCHRIFT 93 (2000) nr 1-2:

T. Antonopoulou - Two Manuscript Collections of the Works of Gregory of Nyssa 1-22; P. Speck - Die Frauen und Söhne Konstantins V. und die Sicherung der Nachfolge 568-585. 
44. BYZANTINOSLAVICA 60 (1999) nr 2:

V. Mayer - Les homélies de s. Jean Chrysostome en juillet 399, 273-303; J. Vaeva - The Notions of Time in Eusebius" "Church History» 304-307; S. Stoytcheva - Bishop Protogenes of Serdica. His life and theological views (335-351), 308-314; S. Patoura - Le rôle historique des Balkans dans le processus de la chute de l'Empire romain d'Occident: le cas des chefs Goths Alaric et Théodoric 367-373; S. Turlej - The Legendary Motif in the Tradition of Patras. St. Andrew and the Dedication of the Slavs to the Patras Church 374-399; W. Seibt - D. Thoedoridis - Das Rätsel der AndrapodaSiegel im ausgehenden 7. Jh.-Waren mehr Slaven oder mehr Armenier Opfer dieser Staatsaktion? 400-406; L. Havlíková - L'influence de la théorie politique Byzantine sur la tradition étatique des Bulgares. Contribution au problème des titres et des symboles de Souverains 407-420.

45. BYZANTION 70 (2000) nr 1-2:

N. Delierneux - L'expoitation des ,topoi” hagiographiques: du cliché figé à la réalité codée 57-90; K. Matchabeli - Remarques sur l'iconographie de la crucifixon sur les stéles géorgiennes du haut Moyen-âge 91-104; M.S.A. Mikhail - Some observations concerning Edibles in Late Antique and Early Islamic Egypt 105-121; J. Schamp - Photios et Jean Philopon: sur la date du "De opificio mundi» 135-154; Th.S. Schmidt - Les "Commentaires» de Basile le Minime: liste révisée des manuscrits et des éditions 155-181; A.D. Vakaloudi - $\Delta \varepsilon \iota \sigma \iota \delta$ ¿uovia and the Role of the Apotropaic Magic Amulets in the Early Byzantine Empire 182-210; B. Janssens - An Unnoticed Witness of Some Works of Maximus the Confessor: Atheniensis, EBE, Metóxıv

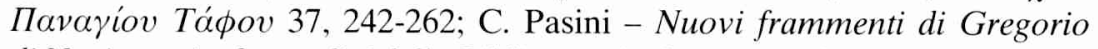
di Nazianzo in due codici della Biblioteca Ambrosiana 263-269; P. Andrist Pour un répertoire des manuscrits de polémique antijudaïque 270-306; H. Elton - Illus and the Imperial Aristocracy und Zeno 393-407; K. Maksimović - Patriarch Methodios I. (843-847) und das studitische Schisma 422446; I. Mossay - Le "Discours» 10 de Grégoire de Nazianze. Notes et controverses 447-455; H.A. Pohlsander - A Call to Repentance Bishop Nicetius of Trier to the Emperor Justinian 456-473; M.D. Smith - The Religious Coinage of Constantius I 474-490; Ch. Térézis - Aspects de la notion de "mal” chez Proclus et chez Denys l'Aréopagite. Une recontre 491-506; P. Yannopoulos - Les vicissitudes historiques de la Chronique de Théophane 527-553.

46. CAHIERS DU CERCLE ERNEST RENAN (2000) nr 209-212:

( $\mathrm{Nr} 209$ ) A. de Benoist - L'incendie de Rome et l'empereur Néron 5-15; ( Nr 210) A. Lama - La tragique victoire d'Héraclius (ou le triomphe de l'Islam) 35-62; (Nr 211) P. Dane - Le mazdéisme (et Mithra) ont-ils influence le Christianisme? 5-14; (Nr 212) J. Magne - Exégèse gnostique du récit du Paradis et sa contre-exégèse 43-49. 
47. CENOBIUM 14 (2000):

Jan Paweł II - List z okazji rozpoczęcia benedyktyńskich obchodów 1500lecia przybycia do Subiaco św. Benedykta, Patrona Europy 5-11; A. Jankowski - Reguła św. Benedykta, rozdziat 67 „O braciach wystanych w podróż" 14-25; M. Van Parys - O powrót do źródeł życia zakonnego wedtug świadectwa Kościotów Wschodnich 26-33.

48. CERKIEWNY WIESTNIK 47 (2000) nr l-4:

(Nr 4) Arcybiskup Szymon - Prawosławna poezja liturgiczna 3-11.

49. CHRIST TO THE WORLD 45 (2000) nr 1:

A.M. Liguori - History of Heresies and Their Refutation, part I, transleted and annotated by A.M. Sutton 38-52.

50. CHRISTUS 47 (2000) nr 185-188:

P. Deseille - Le discernement des Pères du désert 145-153; F. Marxer - La conversion par la lecture. De Claudel à Augustin 273-283.

51. CHURCH HISTORY 69 (2000) nr 1-4:

D.G. Hunter - The Virgin, the Bride, and the Church: Reading Psalm 45 in Ambrose, Jerome, and Augustine 281-303; W. Harmless - Remembering Poemen Remembering: The Desert Fathers and the Spirituality of Memory 483-518; A.S. Jacobs, Writing Demetrias: Ascetic Logic in Ancient Christianity 719-748.

52. CHURCHMAN 114 (2000) nr 1-4:

T. Kirby - The Paradigm of Chalcedonian Christology in Richard Hooker's Discourse on Grace and the Church 22-39; D. Ann Bray - Celtic Spirituality: Its Origins and Interpretations 250-261.

53. CISTERCIAN STUDIES QUARTERLY 35 (2000) nr 1-4:

J. Lawyer - Saint Antony of Egypt and the Spirituality of Aging 55-74; A. De Vogüé - The Criteria of the Discernment of Vocations in the Ancient Monastic Tradition 143-160; D.M. La Corte - Saint Benedict as Model Abbot in the Thought of Aelred of Rievaulx 283-296; T. Vivian - The Coptic Sayings of Saint Macarius of Egypt 499-523.

54. COLLECTANEA CISTERCIENSIA 62 (2000) nr 1-3:

M.E. Cazabonne - Grégoire Palamas (1296-1359) moine, théologien, pasteur (II) 85-99; S. Vantroys - « $\hat{O} F I L S »:$ Notre filiation divine selon Saint Benôit 199-213; A. De Vogüé - Du nouveau sur les «Dialogues» de saint Grégoire 193-198.

55. COLLECTANEA THEOLOGICA 70 (2000) nr 1-3:

(Nr 2) K. Bardski - Świątynia Salomona w Targumie do Pieśni nad Pieśniami 3,7-5,1, 79-92; L. Misiarczyk - Midraszyczne korzenie chrystologicznej interpretacji Prz 8,22 w «Dialogu» Justyna Męczennika 93-107.

56. COMMUNIO (ESP) 33 (2000) nr 1-2:

P. Argárate - La Filosofia en el Prólogo del «Diálogo con Trifón» de San Justino 5-32. 
57. COMMUNIO (PL) 20 (2000) nr 1-6:

(Nr 4) T. Skibiński - Miejsce i rola Apokalipsy św. Jana w poczatkach millenaryzmu chrześcijańskiego 40-53.

58. COMMUNIO (USA) 27 (2000) nr 1-4:

H. Rahner - Odysseus at the Mast 27-45; J.R. Meyer - Clarifying the „Filioque” Formula Using Athanasius's Doctrine of the Spirit of Christ 386-405; R. Darlin Young - Philoxenos of Mabbugh and the Syrian Patristic Understanding of Justification 688-700.

59. COMMUNIO VIATORUM 42 (2000) nr 1-3:

L. Abramowski - Das theologische Hauptwerk des Athanasius: Die drei Bücher gegen die Arianer (Contra Arianos I-III) 5-23.

60. COMPOSTELLE (1999) nr 3:

Ch. Deluz - Saint-Martin de Tours et les chemins de pèlerinage 35-42; H. Jacomet - Saint Martin pèlerin et chevalier: L'apôtre des gaules a-t-il ete un precurseur de saint Jacques? 43-69.

61. CONCORDIA THEOLOGICAL QUARTERLY 64 (2000) nr 1-4:

W.C. Weinrich - Patristic Exegesis as Ecclesial and Sacramental 21-38.

62. CONNAISSANCE DES PÉRES DE L'ÉGLISE (2000) nr 77-80:

(Nr 77: L'Eucharistie) G. Kongs - L'eucharistie, présence du Christ à l'humanité 2-14; I.H. Dalmais - Catéchèse et eucharistie chez les Pères syriaques 15-24; Texte de Jean Chrysostome, trad. L. Brottier 24; J. García - L'eucharistie, sacrement de la communauté selon S. Augustin 25-35; M. Klöckener - La prière eucharistique selon S. Augustin 36-42; A. De Vogüé - Les premiers moines et l'eucharistie 43-54; (Nr 78: Rome) J. Fantino - L'importance de l'Église de Rome au début du christianisme (du I I au III siècle) 2-12; R. Minnerath - Les listes des premiers évêques de Rome 1320; A. Faivre - Les fouilles , in Vaticano”. Bilan et enjeux d'un demi-siècle de débats 21-40; J. Siat - L'apôtre Pierre, vénéré par les fidèles, modèle pour ses successeurs (d'après les inscriptions paléochrétiennes de la Basilique constantinienne de Saint Pierre au Vatican) 41-51; É. Paoli - Présentation de la prosopographie de l'Italie chrétienne 53-55; (Nr 79: Lérins) N. Duval - La naissance de l'édifice chrétien 2-20; J.P. Weiss - Une communauté religieuse aux les de Lérins 21-32; M. Labrousse - Saint Honorat d'Arles, moine et évêque 33-39; J.P. Weiss - Vincent de Lérins 40-48; M. Labrousse - Les moines de Lérins et la théologie augustinienne de la grâce: Hilaire d'Arles et Fauste de Riez 50-53; Y. Escher - Eucher de Lyon 54-57; M.A. Vannier Jean Cassien et Lérins 58-61; (Nr 80: L'Épiphanie) G. Kongs - Épiphanie et Jubilé 2-9; P. Maraval - L'Épiphanie chez les Pères Cappadociens: une fête baptismale 10-16; C. Pasquet - L'Épiphanie dans le monde syriaque 17-31; M.A. Vannier - L'Épiphanie dans le monde latin à partir des textes de S. Augustin et de S. Léon 32-36; A. Louf - Pourquoi Dieu se manifesta, selon Isaac le Syrien? 37-56. 
63. CRISTIANESIMO NELLA STORIA 21 (2000) nr 1-3:

J. Komonchak - Authority and conversion or: the limits of authority 207229; G. G. Lettieri - La metamorfosi del «De doctrina Christiana» di Agostino 263-310; Ph. Badot - D. De Decker - Les «Saintes Familles» de la Spätantike: Héliogabale ou les Orientales au pouvoir? 403-411; C. Buenacasa Pérez - La persecución del emperador Juliano a debate: los cristianos en la politica del último emperador pagano (361-363), 509-529.

64. CURRENDA 150 (2000) nr 1-4:

A. Zurek - Skąd wziąt się rok 2000, 598-608.

65. CZESTOCHOWSKIE STUDIA TEOLOGICZNE 28 (2000):

A. Tronina - Apokryfy Starego Testamentu. Historia publikacji i obecny stan badań 7-23; W. Zyciński - Od „Transitus Mariae” po „Munificentissimus Deus”. Historia dogmatu o Wniebowzięciu Maryi 107-118.

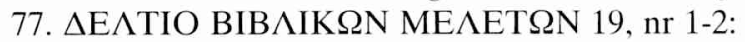

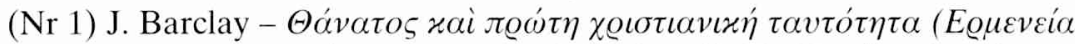

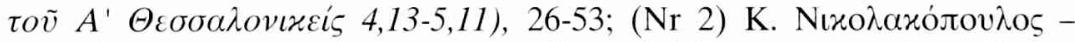

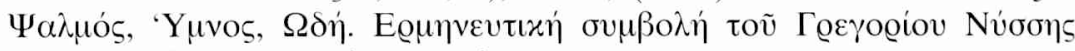

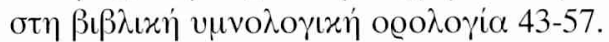

78. DIALOG 3 (2000) nr 5-6:

(Nr 5) W. Dancă - Omul ca imagine a Sfinteii Treimi după sfântul Augustin 69-88; N. Chifăr - Răsăritul și Apusul creștin în apărarea dogmei Sfintei Treimi in secolul al IV-lea 89-106.

79. THE DOWNSIDE REVIEW (2000) nr 410-413:

J. Barnett - Mysticism and the Liturgy in Denys the Areopagite 111-136;

K. Paffenroth - The Young Augustine: Lover of Sorrow 221-230.

80. EARLY MEDIEVAL EUROPE 9 (2000) nr 1-3:

P. Brown - Enjoying the saints in late antiquity 1-24; Ch. Behr - The origins of kingship in early medieval Kent 23-52; C. Cubitt - Sites and sanctity: revisiting the cult of murdered and martyred Anglo-Saxon royal saints 53-83; D. Howlett - A response to 'Lighten Our Darkness' 85-92; N. Everett - Literacy and the law in Lombard government 93-127; S. Sato - The Merovingian accounting documents of Tours: form and function 143-161; M.D. Laynesmith - Stephen of Ripon and the Bible: allegorical and typological interpretations of the "Life of St Wilfrid” 162-182; J. Hill - The „Litaniae maiores” and „minores" $a$ in Rome, Francia and Anglo-Saxon England: terminology, texts and traditions 211-246; M. Sághy - „Scinditur in partes populus”: Pope Damasus and the Martyrs of Rome 273-287; C. Leyser - The temptations of cult: Roman martyr piety in the age of Gregory the Great 289-307; C. Pilsworth - Dating the "Gesta martyrum» a manuscript-based approach 309-324; F. Lifshitz - Gender and exemplarity east of the middle Rhine: Jesus, Mary and the saints in manuscript context 325-343; M. Costambeys - Property, ideology and the territorial power of the papacy in the early Middle Ages (review article) 367-396. 
81. EŁCKIE STUDIA TEOLOGICZNE 1 (2000):

Mejor Mieczysław - Interpretacje znaleziska koptyjskich ksiażek z NagHammaai, „Ełckie Studia Teologiczne” 1 (2000) 187-202.

82. EOS 87 (2000):

A. Drozdek - Infinity in Plato 53-62; A. Klęczar - The Exagoge of Ezechiel: Analysis of the dramatical Structure of the Play 113-118; M. Winiarczyk - Theologische Ansichten des Euhemeros von Messene und ihre Quelle 63-99.

83. EPHEMERIDES LITURGICAE 114 (2000) nr 1-4:

J.N. Pérès - La solidarité fraternelle dans la célébration de l'«agape»pascale selon l'«Épître des Apôtres» 62-68; B. Neil - Anastasius Bibliothecarius'Latin Translation of Two Byzantine Liturgical Commentaries 329-346; Y.N. Yossef - Liturgical Connections between Copts (AntiChalcedonian) and Greeks (Chalcedonian) after the Council of Chalcedon 394-400.

84. EPHEMERIDES THEOLOGICAE LOVANIENSES 76 (2000) nr 1-4:

W. Mayer - Who Came to Hear John Chrysostom Preach? Recovering a Late Fourth Century Preacher's Audience 73-87; R.C. Will - Theodoret, Commentator on the Psalms 88-104; T. Baarda - „Siloam” in John 5,2? Ephraem's Commentary on the "Diatessaron» 136-148; D.J. Bingham Hope in Irenaeus of Lyons 265-282; C. Houtman - Der „Tatian” des Pentateuch: Einheit und Kohärenz in Exodus 19-40, 381-395.

87. ERBE UND AUFTRAG 76 (2000) nr 1-6:

B. Müller - Das Gebet unter Tränen in der Benediktsregel und der «Vita Benedicti» Gregors den Großen (Dial. II) 47.59; A. Böckmann - Vom Cellerar des Klosters wie er sein soll (Regula Benedicti, cap. 31) (I) $197-$ 217, (II) 297-320; K. Oost - Die Bedeutung der Frauengestalten in der Vita des hl. Benedict 236-247; T. Heither - Jesus, der Weg zum Vater 379387; R. Albrecht - Die Anfänge des weiblichen Mönchtums. Ein Versuch 388-400; P. Luislampe - Makrina die Jüngere: Gründergestalt des weiblichen Mönchtums in Kleinasien 458-471; Ch. Reemts - „Vergiss dein Volk und dein Vaterhaus". Das Verlassen der Eltern in der Alten Kirche 484492.

88. ESPE (2000) nr 50-53:

(Nr 50) E. Kryściak - Asceta pełen humoru (św. Antoni Pustelnik) 77-78; Św. Efrem, Mistrzu i Panie (modlitwa) 78; (Nr 51) E. Kryściak - Uczeń św. Jana (św. Polikarp) 79; ( Nr 52) E. Kryściak - Prefekt, który został biskupem (św. Ambroży) 80-81; (Nr 53) E. Kryściak - Niewolnik, który zostat papieżem (św. Kalikst) 74-75.

89. ESTUDIO AGUSTINIANO 35 (2000) nr 1-3:

C. Mielgo - Jesús y los cínicos (I) 5-47, (II) 237-270; P. De Luis - Estructura de la Regla de san Agustín (VIII) 49-77, (IX) 271-290, (X) 483-531. 
90. ESTUDIOS BÍBLICOS 58 (2000) nr 1-3:

Ch. T. Begg - The retellings of the story of Judges 19 by Pseudo-Philo and Josephus: a comparison 33-49; R.C. Hill - Theodoret's commentary on Paul 79-99.

91. ÉTUDES GRÉGORIENNES 27 (2000):

$\mathrm{P}$. Bernard - „La schola cantorum” romaine et les échanges liturgiques avec la Gaule au VI siècle 61-120.

92. FAITH \& REASON 24-25 (1999-2000):

D. Quinn - „Rude and Religious Irish”: The Cult of Wandering Saints in the Middle Ages 3-29.

93. FILOZOFIA (2000) nr 37-38:

(Nr 37) J. Zieliński - Źródła filozofii wczesnochrześcijańskiej-stoicyzm 1332; M. Manikowski - Niepoznawalny Bóg a teofanie Księgi Wyjścia 33-52;

D. Dembińska-Siury - Chrześcijaństwo, hellenizm i tradycja grecka $w I V w$. 53-81; A. Świtkiewicz-Blandzi - Uwagi dotyczace wptywu Pseudo-Dionizego w Kościele Wschodnim (VI-XIV w.) 83-93.

94. FOLIA HISTORICA CRACOVIENSIA 6 (1999):

F. Małaczyński - Rozwój obrzędów zwiąanych z Grobem Pańskim 249254.

95. FOLIA HISTORICA CRACOVIENSIA 7 (2000):

J.J. Janicki - „Dies Domini” - Niedziela w pierwszych wiekach Kościoła 205-219.

96. FOLIA THEOLOGICA 11 (2000):

L. Vanyó - The Patristic Interpretation of „Redemptio” 19-44.

97. FREIBURGER ZEITSCHRIFT FÜR PHILOSOPHIE UND THEOLOGIE 47 (2000) nr 1-3:

B. Studer - Patristische Anstöße zu einer Erneuerung der Trinitätslehre 463483.

98. GREGORIANUM 81 (2000) nr 1-4:

L.F. Ladaria - Jesús y el Espíritu Santo según Gregorio de Elvira 309-329;

L.F. Ladaria - «... Patrem consummat Filius». Un aspecto inédito de la teología trinitaria de Hilario de Poitiers 775-788.

99. GYMNASIUM 107 (2000) nr 1-6:

S. Freund - Philosophorum supercilia contemnimus. Überlegungen zur Bewertung der Philosophie in "Octavius» des Minucius Felix 425-434; J. Holzhausen - Augustin als Biograph und Exeget. Zur literarischen Einheit der «Confessiones» 519-536.

100. HARVARD THEOLOGICAL REVIEW 93 (2000) nr 1-4:

M. Hirshman - Rabbinic Universalism in the Second and Third Centuries 101-115; R.E. Heine - In Search of Origen's Commentary of Philemon 117133; A.A. Jacobs - The Disorder of Books: Priscillian's Canonical Defense of Apocrypha 135-139; R.F. Shedinger - A Note on the Variant Form of the 
"Shema” in the Writings of Justin Martyr 161-163: A. van den Hoek - J.J. Herrmann - Paulinus of Nola, Courtyards and Canthari 173-220; D. Woods - Thessalonica's Patron: Saint Demetrius or Emetrius 221-234; V. Limberis - „Religion” as the Cipher for Identity: The Cases of Emperor Julian, Libanius, and Gregory of Nazianzenus 373-400.

101. HEILIGER DIENST 54 (2000) nr 1-4:

$\mathrm{H}$. Buchinger - Zur Hermenentik liturgischer Psalmenverwendung. Methodologische Überlegungen im Schnittpunkt von Bibelwissenschaft, Patristik und Liturgiewissenschaft 193-222; E. Renhart - Die älteste armenische Anaphora 298-309.

102. HERMENEIA 16 (2000) nr 1-3:

(Nr 1) Mönch Aidan - Heilige des 1. Jahrtausends in Britannien und Ireland (Forsetzung), übersetzt K. Keller, 49-58; (nr 3) 48-57; (Nr 2) S. Maxfield The Causes of Iconoclasm 7-18; St. John Damascene - Apologia against those who decry holy images (part I) 50-56.

103. THE HEYTHROP JOURNAL 41 (2000) nr 1-4:

J.K.A. Smith - Between Predication and Silence: Augustine on How (Not) to Speak of God 66-86.

104. HISTORYKA STUDIA METODOLOGICZNE 30 (2000):

M. Stachura - Pojęcie ,heretycy” w ustawodastwie Konstantyna Wielkiego i jego następców 59-72.

105. IRLANDIA (2000) nr 2(38):

S. Janczyński - Reguła Kolumbańska - fundament monastycyzmu irlandzkiego 1-7.

106. INTERNATIONAL REVIEW OF MISSION 89 (2000) nr 352-355:

T. Mitri - Who Are the Christians of the Arab World 12-27.

107. JOURNAL OF EARLY CHRISTIAN STUDIES 8 (2000) nr 1-4:

G.D. Dunn - The Universal Spread of Christianity as a Rhetorical Argument in Tertullian's «Adversus Iudaeos» 1-19; P.S. Russell - Ephraem the Syrian on the Utility of Language and the Place of Silence 21-37; L. Ayres "Remember That You Are Catholic” (serm. 52. 2): Augustine on the Unity of the Trine God 39-82; J.J. O'Keefe - „A Letter that Killeth”: Toward a Reassessment of Antiochene Exegesis, or Diodore, Theodore, and Theodoret on the Psalms 83-104; Ch.E. Hill - Cerinthus, Gnostic or Chiliast? A New Solution to an Old Problem 135-172; H.W. Attridge - Valentinian and Sethian Apocalyptic Traditions 173-211; P. Cox Miller - ,, The Little Blue Flower is Red": Relics and the Poetizing of the Body 213-236; T.F. Martin. Vox Pauli: Augustine and the Claims to Speak for Paul, An Exploration of rhetoric at the Service of Exegesis 237-272; D. Frankfurter - ,Things Unbefitting Christians": Violence and Christianization in Fifth-Century Panopolis 273-295; A. Siverstev - The Gospel of Thomas and Early Stages in the Development of the Christian Wisdom Literature 319-340; M. Waldstein - 
Hans Jona's Construct „Gnosticism”: Analysis and Critique 341-372; R.A. Layton - Recovering Origen's Pauline Exegesis: Exegesis and Eschatology in the Commentary on Ephesians 373-412; I.J. Davidson - Staging the Church? Theology as Theater 413-452; S.J. Davis - A „Pauline” Defense of Women's Right to Baptize? Intertextuality and Apostolic Authority in the Acts of Paul 453-460; (Nr 4) D. Kruegel - Writing and the Liturgy of Memory in Gregory of Nyssa's «Life of Macrina» 483-510; G. Frank Macrina's Scar: Homeric Allusion and Heroic Identity in Gregory of Nyssa's "Life of Macrina» 511-530; W. Robins - Romance and Renunciation at the Turn of the Fifth Century 531-557; É. Rebillard - A New Style of Argument in Christian Polemic: Augustine and the Use of Patristic Citations 559-578; I.L.S. Balfour - Tertullian On and Off the Internet 579-585.

115. THE JOURNAL OF JURISTIC PAPYROLOGY 30 (2000):

E. Wipszycka - The Nag Hammadi Library and the Monks. A Papyrologist's point of view 179-191.

116. THE JOURNAL OF ECCLESIASTICAL HISTORY 51 (2000) nr 1-3: J. Lössl - Augustine in Byzantium 267-295.

117. THE JOURNAL OF THEOLOGICAL STUDIES 51 (2000) nr 1-2:

V.M. Lang - The Christological Controversy at the Synod of Antioch in 268/ 9, 54-80; Marcellus of Ancyra (Pseudo-Anthimus) - , On the Holy Church”. Text Translation and Commentary by A.H.B. Logan 81-112; R.W. Burgess - The Date of the Deposition of Eustathius of Antioch 150-160; N. Adkin Julian of Eclanum on Psalm 103, 2, 161-163; R.E. Heine - Recovering Origen's Commentary on Ephesians from Jerome 478-514; M. Gockel A Dubious Christological Formula? Leontius of Byzantium and the „ANHYPOSTASIS-ENHYPOSTASIS" Theory 515-532; B. Neil - The Western Reaction to the Council of Nicea II 533-552.

118. KERYGMA UND DOGMA 46 (2000) nr 1-4:

A.M. Ritter - Gebet und Gottesverehrling bei Proklus und Dionysius Pseudo-Areopagita 156-167.

119. КИРИЛО-МЕТОДИЕВСКИ СТУДИИ 13 (2000):

С. Бьрлиева - Климент Румски, Климент Охридски и кирило-методиевската традиция 159-166.

120. KU DOJRZAŁOŚCI W KULTURZE RELIGIJNEJ 6 (2000) nr 11-13:

(Nr 11) Jan Paweł II - List Apostolski „Augustinum Hipponensem” w 1600 rocznice nawrócenia św. Augustyna 6-32.

122. LATERANUM 66 (2000) $\mathrm{nr} 1-2$ :

L.F. Ladaria - La fede in Dio Padre nella Tradizione cattolica 107-128;

R. Penna - L'origine della Chiesa di Roma e la sua fisionomia iniziale 309-322.

123. LES ETUDES CLASSIQUES 68 (2000) nr 1-4:

G. van Coillie - Des ruses de l'intelligence à la prudence et au-delà. Homère, Sophocle, Aristote et Jean Chrysostome 129-145. 
124. LITERATURE \& THEOLOGY 14 (2000) nr 1-4:

M. Kraftson-Hogue - Predication Turning to Preise: Marion and Augustine on God and Hermeneutics - (Giver, Giving, Gift, Giving) 399-411.

125. LITURGISCHES JAHRBUCH 50 (2000) nr 1-4:

H. Buchinger-Patristik und Liturgiewissenschaft. Thematische Streiflichter aktueller Forschung 64-66.

126. LOGOS I ETOS (2000) nr 8-9:

(Nr 8) M. Drwięga - Kilka uwag o antropologii św. Augustyna 151-160.

127. LA MAISON DIEU (2000) nr 221-224:

X. Frisque - Le chant au Christ chez. Ambroise. La foi de Nicée dans ses hymns 101-128; A. Hamman - ,Koinonia, Diakonia and Martyria. A propos d'un livre récent $141-150$

128. MEANDER 55 (2000) nr 1-4:

P. Rabiej - Czy Maksymin Trak prześladowat chrześcijan? Próba ogólnej prezentacji zagadnienia 221-232; D. Spychała - Konstantyn II wobec sporu ariańskiego (lata 337-340), 233-238; M. Pawlak - Rywalizacja o stanowisko naczelnego wodza (magister utriusque militiae) w zachodniej części Imperium Romanum w latach 425-430 a inwazja Wandalów na Afrykę 239-254.

129. MEDIEVAL ENCOUNTES 6 (2000) nr 1-3:

L.S.B. MacCoull - Notes on the Martyrdom of John of Phanijoit (BHO 519), 58-79.

130. MÉLANGES DE L'ÉCOLE FRANÇAISE DE ROME 112 (2000) nr 1 (Moyen Âge):

A. Desreumax - Alexandre, La Couronne et la Croix. La vêve syriaque du royaume perdu 43-49.

131. MELITA THEOLOGICA 51 (2000) nr 1-2:

H. Drobner - „You Cannot Pick Grapes from Thornes”: Saint Augustine's Archaeological Evidence and Spiritual Meaning 25-37; H. Scerri - „Koinonia, Diakonia and Martyria”; Interrelated Themes in Patristik Sacramental Theology as expounded by Adelbert G. Hamman O.F.M. 75-83; H.R. Drobner - „I would rather not be wearisome to you”. Saint Augustine as preacher $117-126$.

132. MIEJSCA ŚWIĘTE 29 (2000) nr 1-4, 10-11:

(Nr 1) J. Naumowicz - Ojcowie Kościoła mówia. Niezapisane stowa Jezusa 47; (Nr 2) J. Naumowicz - Ojcowie Kościoła mówią. Jak Maryja utkała purpurę 53; (Nr 3 ) A. Rak - Irlandia św. Patryka 46-47; (Nr 4) A. Kuśmirek - Nowa Jerozolima 18-20; D. Żarska - Pępek świata. Civitas Dei 35-39; (Nr 10) P. Bieliński - Sztuka Koptów czyli radość wiary $64 ;(\mathrm{Nr} 11)$ B. Fabiani - Podziemne miasto zmartych 7-9; Prawdziwe życie po śmierci 9-11; Sanktuaria męczenników 12-13; Kolebka sztuki chrześcijańskiej 14-16; J.S. Partyka - Kopalnie relikwii 18-23; J. Gać - Kaplica Sykstyńska kata- 
kumb 24-29; M.M. Matusiak - Nowe życie w starym świecie. Codzienność chrześcijanina pierwszych wieków 30-32.

133. MILES IMMACULATAE 36 (2000) nr 1-2:

S. Perrella - La Theotokos e Aeiparthenos nella storia della fede. Il Contributo del Magistero e della teologia contemporanea 50-119.

134. MISCELLANEA HISTORICO-ARCHIVISTICA (2000) t. 11-12:

(T. 12) A. Wąsik - Kwestia sukcesji po Konstantynie Wielkim. Masakra rodziny cesarskiej w 337 r., 143-151.

135. MITTELLATEINISCHES JAHRBUCH 35 (2000) nr 1-2:

H. Gneuss - Zur Geschichte des Hymnars 227-247; T.A.P. Klein - Reimgebet oder Heiligenleben? Rekonstruktions-versuch einer neuaufgefundenen «Vita Theophili metrica» 267-288; D. Gall - Augustinus auf dem Mt. Ventoux: Zu Petrarcas Augustinus-Rezeption 301-322.

136. MNEMOSYNE 53 (2000) nr 1-6:

D. Woods - Ammianus Marcellinus and the „Rex Alamannorum” Vadomarius 690-710.

137. MÓWIĄ WIEKI (2000) nr 1-12:

(Nr 4) P. Janiszewski, Świętość i korupcja: prezenty patriarchy Cyryla 6-11; ( $\mathrm{Nr}$ 8) P. Janiszewski - Era dionizyjska a rzeczywista data narodzin Jezusa 7-11; (Nr 9) M.B. Leszka - Cesarzowa Eudoksja i Jan Chryzostom. $Z$ dziejów pewnego konfliktu 6-10.

138. MÜNCHENER THEOLOGISCHE ZEITSCHRIFT

M. Weittlauf - Zur Bedeutung des Mönchtums für die geschichtliche Überlieferung 161-170.

139. MUSEUM HELVETICUM 57 (2000) nr 1-4:

Ch. Riedweg - Zur handschriftlichen Überlieferung der Apologie Kyrills von Alexandrien "Contra Iulianum» 151-165; H. Marti - Vom Schicksal des Basileios im Westen. Beobachtungen zu Rufins Predigt-Übersetzungen 166-172; F. Paschoud - Symmaque, Jérôme et l'«Histoire Auguste» 173-182; M. Puelma - „Catastolium”: ein problematischen Gräzismus bei Augustin 183-192; A. Weische - Eigentümlich Lateinisches und Ciceronisches bei Augustinus als Basis für Anselms Gottesbeweis 193-200.

140. NEDERLANDS THEOLOGISCH TIJDSCHRIFT 54 (2000) nr 1-4:

J.N. Bremmer - The Passion of Perpetua and the Development of Early Christian Afterlife 97-111.

141. NEUE ZEITSCHRIFT FÜR MISSIONSWISSENSCHAFT 56 (2000) nr 1-2:

J. Varoqui - L'apologue de Jonas. Un antique exemple d'inculturation chrétienne 81-96.

142. NICOLAUS 27 (2000) nr 1-2:

R. di Benedetto di Gioia - La teoria dei segni nel «De doctrina christiana» di Agostino 263-270; M. Pia Pagani - I Santi stolti di Costantinopoli 319-338; 
R. Salvemini - Empietà e follia nella caratterizzazione degli eretici. Alle origini del lessico di Fozio 355-389; H. Scerri - Piste per una teologia del sacramento della penitenza in due preghiere penitenziali dell'Eucologio Patriarcale Constantinopolitano (secoli VIII, XI) 425-438.

143. NOMOS (1999/2000) nr 26-29:

(Nr 26/27) A. Lebet-Minakowska - Symbolika religijna starożytnego Egiptu na tkaninach koptyjskich 99-111; (Nr 28/29). П. Дмоховский - Монатество в Христианстве до разделения церквей 75-77; М. И. Золотарев, Д. Ю. Коробков - О крещении жителей Херсонеса Таврического е IV веке 131-140; О. Я. Савеля, Т. Сарновский - Римские воинские культы в Крьмм 141-145.

144. NOWY FILOMATA 4 (2000) nr 1-4:

S. Stabryła - Poeta Seduliusz 119-126; J. Sondel - Kodeks Justyniana jako podstawa prawna $w$ postępowaniu sq̨dowym o „crimen laesae maiestatis” w osiemnastowiecznej Polsce 143-148; A. Wójtowicz - Tertulian a początki polemiki w tacińskiej literaturze chrześcijańskiej 179-190; K. Twardowska Jan i Eudoksja 201-206; K. Rekucka-Bugajska - J. Bugajski - Warsztat brazownika w starożytności 207-219;

145. NOVUM TESTAMENTUM 42 (2000) nr 1-4:

J. Schröter - Jerusalem und Galiläa. Überlegungen zur Verhältnisbestimmung von Pluralität und Kohörenz für die Konstruktion einer Geschichte des früher Christentums 127-159; D.M. Scholer - Bibliographica Gnostica: Supplementum II/3, 39-83; Ch. Heil - Arius Didymus and Luke-Acts 358393.

146. NUMEN 47 (2000) nr 1-4:

$\mathrm{K}$. von Stuckrad - Jewish and Christian Astrology in Late Antiquity: A New Approach 1-40.

147. ORDENS NACHRICHTEN 39 (2000) nr 1-6:

(Nr 6) Regula: Ordensregeln als spirituelle Impulse. Eine Sendereihe des Radiokollegs des ORF (Augustinus, Benedikt, Franziskus, Ignatius) 51-70. 148. ORIENTALIA CHRISTIANA PERIODICA 66 (2000) nr 1-2:

K.H. Uthemann - Severian von Gabala in Florilegien zum Bilderkult 5-47; W. Mayer - Cathedral Church or Cathedral Churches? The Situation at Constantinople (c. 360-404 AD) 49-68; V. Ruggieri - G.C. Zaffanella La valle degli eremiti nel canyon del Koça Çay a Kızılbel in Licia 69-88; M. Van Esbroeck - David Tserouni sur la hiérarchie ecclésiastique. Un traité arménien du VII siècle 89-117; W. Becket Soule - The Stauropegial Monastery 147-167; C. Pasini - Nuovi frammenti basiliani nell'Ambrosiano A 245inf. 169-171; M.E. Bottecchia Dehò - Nota a un testo delle Costituzioni Apostoliche. Libro VIII, capitolo 46, 173-183. D. Brakke - The Egyptian Afterlife of Origenism: Conflicts over Embodiment in Coptic Sermons 277-293; F. Pericoli Ridolfini - Dedica e Sommario del «De opificio homi- 


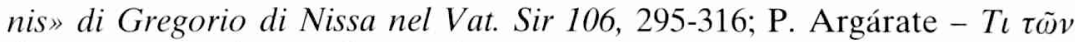

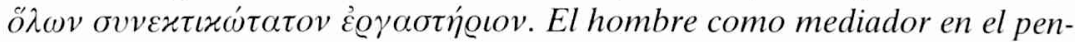
samiento de Máximo el Confesor 317-334; E. Lucchesi - Un nouveau témoin copte du "Sermon sur la conduite chrétienne» du Pseudo-Chenouté 419-422. 149. ORIENTE CRISTIANO 39 (2000) nr 1-3:

(Nr 1) A. Calisi - L'immagine della Sindone e l'iconografia bizantina 12-22. 152. PASTORES (2000) nr 6-8:

(Nr 6) J. Naumowicz - Nieustanna pamięć o Bogu 62-68; J. Krykowski Imiona Jezusa 114-120; ( Nr 7) J. Naumowicz - Docenić przebaczenie (teksty patrystyczne) 109-114

153. PAST \& PRESENT (2000) nr 166-168:

(Nr 166) J. - P. Devroey - Men and Women in Early Medieval Serfdom: The ninth-century North Frankish Evidence 3-30; (Nr 167) P. Crone - Ninthcentury Muslim Anarchists 3-28; (Nr 168) P.S. Barnwell - Emperors, Jurists and Kings: Law and Custom in the Late Roman and Early Medieval West 6-29.

154. PENSAMIENTO 56 (2000) nr 214-216:

F.M. Hidalgo - San Agustín: Asombro ante el enigma de la propria existencia $125-138$.

155. PEREGRINUS CRACOVIENSIS (2000) nr 8-10:

(Nr 8) A. Naumow - Święta Góra Athos 39-54; B. Gierek - Lough Derg Czyściec świętego Patryka 55-78.

156. PIOTRKOWSKIE ZESZYTY HISTORYCZNE 2 (2000):

S. Bralewski - Mnisi na Soborach i synodach organizowanych przez Cesarzy we wczesnym Bizancjum 5-25.

157. THE POLISH JOURNAL OF BIBLICAL RESEARCH 1 (2000) nr 1:

A. Pawlaczyk - The Motif of Silence in Philo's of Alexandria 127-132.

158. POLONIA SACRA 4 (2000) nr 6-7:

J.W. Żelazny - Montanizm. Heterodoksyjny ruch charyzmatyczny z drugiej polowy II wieku 283-292.

159. PRAWO (2000) nr 270:

R. Wojciechowski - Rodzaje „societates” w prawie justyniańskim 19-32.

160. POZNAŃSKIE STUDIA TEOLOGICZNE 9 (2000):

Augustyn - O tasce Bożej przeciw herezji pelagiańskiej. List 186, tłum. i wstęp A. Strzelecka 53-74; Cezary z Arles - $O$ tasce, $O$ tajemnicy Trójcy Świętej, tłum. Anna Strzelecka, wstęp Paweł Wygralak 75-97; A. SwobodaRola męża we wspólnocie małżeńskiej w pismach Plutarcha $z$ Cheronei i autorów chrześcijańskich IV wieku 99-129; W. Steffen - Od filologii do patrologii (Jan Sajdak 1882-1967), 131-144.

161. PRO ECCLESIA 9 (2000) nr 1-2:

J. Behr - The Word of God in the second Century 85-107; L.G. PattersonMethodius of Olympus and the Plan of Salvation 228-235. 


\section{PROBLEMOS 57 (2000):}

T. Kačerauskas - Origeno ir Platono poetiniai siekiai 44-57.

163. PROCHE ORIENT CHRÉTIEN 49 (1999) nr 1-4:

L. Cremaschi - Jusqu'au dernier souffle. Passions et lutte spirituelle chez les Pères du désert 7-33; S.C. Mimouni - Qui sont les Galiléens dans la littérature chrétienne ancienne? 53-67; Isaac le Syrien - Ne juge pas les autres 227228; D. Attinger - Intransigeance et douceur. Une lecture des Grandes Règles de saint Basile 229-256.

164. PROCHE ORIENT CHRÉTIEN 50 (2000) nr 1-2:

B. Bitton-Ashkelony - A. Kofsky - Gazan Monasticism in the Forth-Sixth Centuries: from Anachoretic to Cenobitic 14-62; J. Corbon - La prière chrétienne 63-79.

165. PRZEGLĄD POWSZECHNY 117 (2000) t. 30, nr 1-12:

(Nr 10) M. Blaza - Kiedy nastapiła Wielka Schizma 44-60; N. LobkowiczQuid est tempus. Interpretacje naszego pojmowania czasu od presokratyków do Augustyna, tłum. J. Zakrzewski, 311-325.

166. PRZEGLĄD PRAWOSŁAWNY (2000) nr 1-12:

(Nr 3) M. Niegierewicz - Duchowość świętych Kosmy i Damiana 18-19. 167. PRZEGLĄD RELIGIOZNAWCZY (2000) nr 195-197:

(Nr 196) A. Jocz - Pomiędzy filozofia a gnostycyzmem. Orygenesa poszukiwanie drogi do poznania rzeczywistości metafizycznej 3-12; ( $\mathrm{Nr} 197) \mathrm{A}$. Ługiewicz - Antyczna magia i religia 3-17; J. Iluk - Jan Chryzostom przeciw judaizmowi i judaizantom 31-70 (ss. 53-69: przekład Pierwszej mowy przeciwko Żydom); A. Pająkowska - Julian Apostata a „restitutio Romanae religionis" 71-77; I. Milewski - Okoliczności śmierci biskupów wschodniorzymskich w IV i V wieku. Przyczynek do dziejów Kościoła późnoantycznego 99-112.

168. PRZEGLĄD TOMISTYCZNY 8 (2000):

L.J. Bataillon - Edycje tacińskich tekstów średniowiecznych, tłum. I.M. Radziejowska 325-336.

169. QUESTIONES SELECTAE 7(2000) nr 10-11:

(Nr 11) A. Kurowska - F.M. Kosiński - Asymilacja tradycyjnej kultury celtyckiej przez wczesne chrześcijaństwo irlandzkie 113-142.

170. RELIGIÓN Y CULTURA 46 (2000) nr 212-215:

A. Ginzo Fernández - El Evangelio según San Juan y la tradición filosófica 169-184; P. Langa Aguilar - Dios Trinidad, vida compartida. Reflexiones desde San Agustín 273-299; S. González - La vivencia trinitaria en San Agustín («De la Trinidad» y «Sermón 52») 301-317; L. Nos Muro - También Dios tiene su propia familia (y por cierto bien curiosa) 319-335; J. Domínguez Sanabria - Llamados a vivir con las tres divinas personas 337-355; S. Sierra Rubio - Respuesta agustiniana a los retos del presente

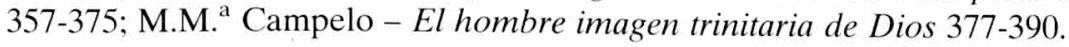


171. RELIGIONEN UNTERWEGS 6 (2000) nr 1-4:

(Nr 2) Ch. Schirrmacher - J. Slomp - Das „Evangelium des Barnabas”. Hintergründe einer Polemik 10-16.

172. REVISTA AGUSTINIANA 41 (2000) nr 124-126:

R.M. García - „Magis esse” y ,minus esse” en San Agustín y una posible influencia neoplatónica 626-636; M.J. Aldana García - La visión negativa del mundo musulmán en el pensamiento de San Eulogio: La belleza frente a la fealdad 637-648; M. Á. Navarro Girón - «La Ciudad de Dios» de San Agustín. Materiales para el estudio (V) 689-748.

173. LA REVISTA CATÓLICA 100 (2000) nr 125-127:

S.E. Fenández - Oración mariana del siglo III, 56-59; S.E. Fernández Buscadores de Dios: San Agustín y la Biblia 268-270.

174. REVISTA ESPAÑOLA DE TEOLOGIA 60 (2000) nr 1-4:

J. Escribano-Alberca - Los apologetas y Clemente de Alejandría. Repulsa y aceptación de la paideia $65-83$.

175. REVISTA TEOLOGICÃ 10 (2000) nr 1-2:

(Nr 2) V. Grjdian - Semnificaia ciclului liturgic la Sf. Vasile cel Mare 65-73; M. Telea - Miscarea isihastă și legăturile cu românii 74-110; P. Ierima Epoca irodiană după scrierile lui Iosif Flaviu 128-163.

176. REVUE DES ÉTUDES AUGUSTINIENNES 46 (2000) nr 1-2:

G. Heidl - Some traces of an ancient Latin compilation of Origen's «Commentary on Genesis» 3-30; M. Dulaey - Á quelle date Augustin a-t-il pris ses distances vis-à-vis du millénarisme? 31-60; M.-O. Boulnois - Liberté, origine du mal et prescience divine selon Cyrille d'Alexandrie 61-82; A. Valevicius Les 24 homélies «De statuis» de Jean Chrysostome 83-91; Y. Duval - Le dèbut de la persécution de Déce à Rome (Cyprien, Ep. 37) 157-172; C. Di MartinoIl ruolo della ,intentio" nell'evoluzione della psicologia di Agostino: dal «De libero arbitrio» al «De Trinitate» 173-198; M. Dulaey - Note augustinienne: les donatistes et les grenouilles 199-204; A.M. Turcan-Verkerk - Faut-il rendre à Tertullien l' «Ex libris Tertulliani de execrandis gentium diis» du manuscrit Vatican latin 3852? I. La composition et l'origine du Vat. Lat. 3852: un dossier constituté par Florus de Lyon 205-234; M. Turcan - Faut-il rendre à Tertullien $l$ " Ex libris Tertulliani de execrandis gentium diis» du manuscrit Vatican latin 3852? II. Tertullien et le fragment "De execrandis gentium diis» 235-271; Chronica Tertullianea et Cyprianea 2000, 273-271; Bulletin Augustinien pour 1999/2000 et compléments d'années antérieurs 313-375.

177. REVUE DES SCIENCES PHILOSOPHIQUES ET THÉOLOGIQUES 84 (2000) nr 1-4:

A. Levy - Aux confins du créé et de l'incréé: les dimensions de l'épectase chez Grégoire de Nysse 247-274; J.M. Fontanier - Sur l'analogie augustinienne „honestum / utile / frui / uti” 635-642; B. Meunier - Bulletin de patrologie. Annexe par X. Moralès 643-684. 
178. REVUE DES SCIENCES RELIGIEUSES 74 (2000) nr 1-4:

M.O. Boulnois - L'eucharistie, mystère d'union chez Cyrille d'Alexandrie: les modèles d'union trinitaire et christologique 147-172; B. Pouderon M.J. Pierre - B. Outtier - Á propos de l'Apologie d'Aristide. Recherches sur un prototype commun aux versions syriaque et armenienne 173-193; G. Dorival - Les chrétiens de l'Antiquité face à la culture classique et à l'hellenisme 419-436; E. Jaffelin - Le temps de l'example (Tertullien) 437-465.

179. REVUE D'HISTOIRE ECCLÉSIASTIQUE 95 (2000) nr 1-3:

(Nr 3) S. Boesch Gajano - Des „Loca sanctorum” aus espaces de la sainteté: étapes de l'historiographie hagiographique 48-70; M. Lamberigts - Pélage: la rehabilitation d'un hérétique 97-111; W. Löhr - The Theft of the Greeks. Christian Self Definition in the Age of Schools 403-426.

180. REVUE D'HISTOIRE ET DE PHILOSOPHIE RELIGIEUSES 80 (2000) nr 1-4:

M. Hengel - 'Iovdaí in der geographischen Liste Apg 2, 9-11 und Syrien als „Großjudäa” 51-68; J. M. Rosenstiehl - Un voyage dans l'Au-delà, vers l'an mil. Brèves remarques autour d'une apocalypse byzantine 93-104; J. Joosten - Jésus el l'aveugle-né (Jn 9, 1-34) dans l'"Évangile de Barnabas» et dans le «Diatessaron» 359-369.

181. LA REVUE REFORMEE 51 (2000) nr 206-210:

(Nr 206) J.M. Daumas - Troubles et attentes millénaires 90-99; ( $\mathrm{Nr} 209$ ) J. van Oort - Augustin aujourd'hui 51-65.

182. REVUE THÉOLOGIQUE DE LOUVAIN 31 (2000) nr 1-4:

B. Hort - Millénarisme ou amillénarisme? Regard contemporain sur un conflit traditionel 33-42.

183. RHETORICA 18 (2000) nr 1-4:

D.L. Sullivan - Ch. Anibale - The Epideictic Dimension of Galatians as Formative Rhetoric: The Inscription of Early Christian Community 117-145. 184. RIVISTA DI TEOLOGIA. ASPRENAS 46 (1999) nr 1-4:

M. Pietrobelli - Il cristianesimo delle origini e la risurrezione della carne 353-372.

185. RIVISTA DI TEOLOGIA MORALE 32 (2000) nr 125-128:

F. Ruggiero - I volti della pace nell' «Epistolario» di Agostino d'Ippona 449455.

186. ROCZNIKI HUMANISTYCZNE 47 (1999) nr 4 + Nr specjalny:

(Nr 4: Historia Sztuki) R. Knapiński - Ojcowie Kościoła o znaczeniu obrazów w przekazie wiary 5-22; (Nr specjalny) A.J. Frejlich - Jak mnich stawat się aniotem 37-48; R. Bulas - Obraz natury we wczesnośredniowiecznej poezji iryjskiej 49-55.

187. ROCZNIKI HUMANISTYCZNE 48 (2000) nr 3-4:

(Nr 3: Filologia Klasyczna) R. Popowski - Dostęp ikonografii do bóstwa 
według mitologii $i$ filozofii greckiej oraz wedtug Biblii 48 (2000) 5-20; H. Wójtowicz - Alegoreza w «Paschale carmen» Seduliusza 93-109. 188. ROCZNIKI NAUK PRAWNYCH 10 (2000) nr 1:

(Nr 1: Prawo) M. Wójcik - Pojęcie i typy fundacji w prawie rzymskim 17-38 189. ROCZNIKI TEOLOGICZNE 47 (2000) nr 1-8:

(Nr 2: Teologia Dogmatyczna) K. Klauza - Soteriologia pozagreckiej teologii pierwszego tysiąclecia. Przegląd źródeł 105-117; (Nr 4: Historia Kościoła) R. Selejdak - Józef Egipski jako figura Chrystusa w dziełach Ojców Kościoła pierwszych czterech wieków 5-24; S. Koczwara - Starania papieża Hormizdasa na rzecz przywrócenia jedności $w$ Kościele $w$ latach 515-517, 25-36; (Nr 5: Teologia Duchowości) J.M. Popławski - Reguła św. Augustyna $i$ jej główne przesłanie 19-25; S.T. Zarzycki - $O$ jedność kontemplacji i działania - św. Augustyn i Mistrz Eckhart 67-92; (Nr 8: Liturgika) J. Sroka - Niedziela dniem Pana. Od szabatu do niedzieli 9-32; Z. Wit - Niedziela dniem Chrystusa 33-56.

190. SACRA DOCTRINA 45 (2000) nr 1-6:

(Nr 1) A. Carpin - Conversione e penitenza in Isidoro di Siviglia 5-64; ( $\mathrm{Nr} 3-$ 4) A. Carpin - La Redenzione in Origene 11-67.

191. SACRIS ERUDIRI 39 (2000):

C.T. Begg - The Dynastic Promise according to Josephus 5-19; P. Hamblenne - Deux métaphores apponiennes (In Cant., III, l. 92 s. Et IX, l. 110112), 21-35; W. Dunphy - An Unlisted Profession of Faith (Pseudo-Rufinus, "De fide») 37-53; G. Partoens \& T. Swaenepoel - „Pariator”. La présence d'un mot rare dans les sermons de saint Augustin 55-66; N. Adkin - Apollonius of Tyana in Jerome 67-79; R. Jakobi - Studien zur lateinischen Fassung des Psalmenkommentars des Theodorus von Mopsuestia 81-97; Th. Gärtner - Zum mittelalterlichen Nachleben der spätantiken Genesisversifikation 'Alethia' des Claudius Mariu Victorius 99-103; J. Leemans Thirteen Years of Athanasius Research (1985-1998). A Survey and Bibliography 105-217; B. Roosen - Athous, Koutloumosiou 39. An Interesting Case 219-252; A. Firey - Carolingian Ecclesiology and Heresy. A Southern Gallic Juridical Tract against Adoptionism 253-316.

192. SAECULUM CHRISTIANUM 7 (2000) $\mathrm{nr}$ 1-2:

S. Longosz - Bibliografia prac ks. prof. dra hab. Emila Stanuli 13-25; M. Wrześniak - Koloseum. Od rzymskiego amfiteatru do chrześcijańskiej świątyni 199-219.

193. SALESIANUM 62 (2000) nr 1-4:

K. Smolak - La poesia cristiana latina tra il quarto e il quinto secolo 19-39; K. \& M. Zelzer - Gli inni di sant'Ambrogio 41-57; J.C. Lechner - «Les sources de Théodore, vierge et martyre» de Pierre Corneille et quelques réflexions sur l'échec de cette „tragédie chrétienne” 58-89; L. Schwarz Romanorum hystoria mistice interpretata. Dal Ven. Beda ai «Die Gesta- 
Romanorum-Handschriften” di Innsbruck. Frammenti di „storia” come esortazione per vivere cristianamente 253-297; F. Bergamelli - Dal Padre al Padre. Il Padre come principio e termine del Cristo e del cristiano in Ignazio di Antiochia 421-431; E. Dal Covolo - Escatologia e apocalittica nei primi secoli cristiani. Il Regno di Dio e la sua attesa negli Apologisti greci de II secolo 625-643.

194. SALVATORIS MATER 2 (2000) nr 1-4:

(Nr 1) J. Królikowski - „Theotokos” w teologii św. Atanazego. Przetom mariologiczny w IV wieku i jego znaczenie 56-73; J.St. Partyka - Najstarsze wizerunki Matki Bożej z rzymskich katakumb 272-291. (Nr 2) B. Kochaniewicz - Łk 1,35 w interpretacji Ojców Kościoła 46-83; S. Longosz - Bogarodzica w nauce Ojców Kapadockich 84-104; M. Zachara - Uroczystość Świętej Bożej Rodzicielki w liturgii rzymskiej I tysiąclecia 124-137; ( Nr 4) B. Kochaniewicz - Matka Boża w „Mowach” Leona Wielkiego 308-332.

195. SAPIENZA 53 (2000) nr 1-4:

A. Vaccaro - L'ermeneutica di S. Agostino sui passi oscuri della Bibbia 87-97.

196. SCANDINAVIAN JOURNAL OF THE OLD TESTAMENT 14 (2000) nr 1-2:

J. Christensen - A Problem in Pseudo-Philo and Its Possible Solution 315-317.

197. SCIENCE ET ESPRIT 52 (2000) nr 1-3:

S.E. Kinsella - The transformation of the Jewish Passover in an early Christian liturgy. The influence of the Passover "Haggadah» in the "Apostolic Tradition» 215-226; S.E. Kinsella - The transformation of the Jewish Passover in an early Christian liturgy: The influence of the Passover Haggadah in the Apostolic Tradition 215-228.

198. SCOTISH JOURNAL OF THEOLOGY 53 (2000) nr 1-4:

C. Gunton - Election and Ecclesiology in the Post-Constantinian Church 212-227.

199. SCRIPTA THEOLOGICA 32 (2000) nr 1-3:

L.F. Matteo-Seco - ,Envió Dios a su Hijo, nacido de mujer” (Gálatas 4, 4-5 en el pensamiento patrístico anterior al Concilio de Éfeso) 13-46; H.R. Drobner - El Salmo 21 en los «Sermones ad populum» de San Agustín 413-432; J.L. Gutiérrez Martín - „Un testimonio de la primitiva "paleoanáfora» latina" Rastros del formulario anáforico africano en la obra de Optato, obispo de Milevi 801-834.

200. SEMINARE 16 (2000):

J. Nowiński - Idea „Sancta Sanctorum” i Arki przymierza towarzyszaca przechowywaniu Eucharystii we wczesnośredniowiecznych świqtyniach 537-548; T. Kołosowski - Sakramenty w nauczaniu i praktyce duszpasterskiej biskupa Cezarego z Arles 449-464. 
201. SOTER (2000) nr 3(31):

B. Gudaityè - Ikona kaip žodis 63-74.

202. STUDIA ALOISIANA (2000):

H. Panczová - Grécizmy a hebrejizmy v krestánskej latinčine 185-225; S.Th.

Caecilius Cyprianus - "Liber de Catholicae Ecclesiae unitate». Kniha o jednote Katolíckej Cirkvi, preložila T. Sukopová 367-380.

203. STUDIA ANSELMIANA 129 (2000):

B. Studer - Johannes 5, 19 f. in der Trinitätslehre der Kirchenväter 515-542;

A. de Vogüé - Obéissance et autorité dans le monachisme ancien jusqu'à saint Benoit 565-600; K. Belsole - ,With the Joy of the Holy Spirit” (1 Thess. 1:6): the Pauline Background to Joy in Lent in RB 49, 601-620; E. Bianchi„Quaerere Deum” oggi nella vita monastica 647-657.

204. STUDIA GNESNENSIA 14 (2000):

B. Czyżewski - Symbol a prawda w «Homiliach Paschalnych»Pseudo Chryzostoma 77-102.

205. STUDIA HISTORYCZNO-TEOLOGICZNE ŚLĄSKA OPOLSKIEGO 20 (2000):

N. Widok - „Physis” w literaturze wczesnochrześcijańskiej (od czasów biblijnych do Soboru Nicejskiego) 143-157.

206. STUDIA LOVICENSIA. ŁOWICKIE STUDIA TEOLOGICZNE 2 (2000):

J. Krykowski - Szkic o początkach chrześcijaństwa $w$ Trydencie: biskup Wigiliusz, męczennicy z. Anaunii i pustelnik Romediusz 157-166; J. Krykowski - L'eredità di Tertuliano e di Cipriano nel $4^{\circ}$ secolo 167-181.

207. STUDIA MEDIEWISTYCZNE 34-35 (2000):

A. Świtkiewicz-Blandzi - Notes about Denys Areopagite's the „Ecclesiastical Hierarchy" and Its Influence on St. Maximus the Confessor's "Mystagogy» 55-70.

208. STUDIA MONASTICA 42 (2000) $\mathrm{nr}$ 1-2:

G. Bunge - „La Montagne intelligible”. De la contemplation indirecte à la connaissance immediate de Dieu dans le traité «De Oratione» d'Évagre le Pontique 7-26; J. Driscoll - The Fathers of Poemen and the Evagrian connection 27-51; F. del Río Sánchez - Abrahám de Natpar 53-63; A.A. Navarrete - San Benito y Justiniano (II) 113-156; M. Sheridan - Job and Paul: Philosophy and Exegesis in Cassian's sixth Conference 271-294; P. Argárate

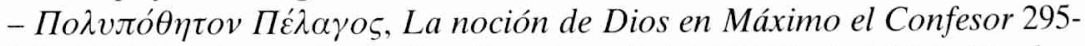
317; T.G. Kardong - Self-will in Benedict's Rule 319-346; F. del Río Sánchez - Tres „membrê” de Abrahám de Natpar: edición y traducción del Cod. Vat. Syr. 593 (ff. 16-66), 347-377.

209. STUDIA PŁOCKIE 28 (2000):

W. Turek - ,Wierzymy w Ojca, i Syna, i Ducha Świętego”: bóstwo i pochodzenie Ducha Świętego w ujęciu św. Bazylego Wielkiego (+379) 49-56; 
L. Misiarczyk - Ewangeliczny tekst ustanowienia Eucharystii wedtug świadectwa 1 Apologii 66,3 Justyna Męczennika 69-80.

210. STUDIA RELIGIOLOGICA (2000) nr 33 (Absolut - Istota Najwyższa Bóg w religiach i dociekaniach filozoficznych):

H. Pietras - Pojęcie Bożej substancji u Orygenesa. Próba ujęcia 127-140; E. Przybył - M. Bzinkowski - Wokót problematyki definiowania Boga. Prawosławne wyznania wiary św. Grzegorza Palamasa i patriarchy Gennadiosa Scholariosa 235-246.

211. STUDIA THEOLOGICA VARSAVIENSIA 38 (2000) nr 1-2:

T. Bartoś - Wybrane zagadnienia teologiczne i filozoficzne pojawiające się w kontekście użycia nazwy „miłość” $w$ odniesieniu do Boga w Komentarzu św. Tomasza z Akwinu do „De divinis nominibus” Pseudo-Dionizego Areopagity 33-63.

212. STUDIA WŁOCŁAWSKIE 3 (2000):

T. Kaczmarek - „Descendit od inferos”: prawda zbawcza przekazywana w szacie języka starożytnego 111-122; Z. Wróbel - «De patientia» Quinti Septimi Florentis Tertulliani. Zagadnienie genezy, rodzaju literackiego i kompozycji 323-353.

213. ST. VLADIMIR'S THEOLOGICAL QUARTERLY 44 (2000) nr 1-4:

D.F. Stramara - Introspection in the Ancient Mediterranean World: Taking a Closer Look 35-60; R.C. Hill - Chrysostom's Homilies on David and Saul 123-141; C.P. Schroeder - The Mystery of Love: Paradigms of Marital Authority and Submission in the Writings of St John Chrysostom 143-168; N.V. Harrison - The Inevitability of Hermeneutics: David C. Ford on St John Chrysostom 195-205; S.S. Horuzhy - Neo-Patrsitic Synthesis and Russian Philosophy 309-328; V. Shevzov - The Icon of Mary in Russian Akathistoi Hymns 343-373.

214. SYMBOLAE PHILOLOGORUM POSNANIENSIUM 15 (2000):

A. Pawlaczyk - Paradoks wolności i niewoli. Postać Heraklesa w pismach Filona z Aleksandrii 49-58.

215. ŚLĄSKIE STUDIA HISTORYCZNO-TEOLOGICZNE 33 (2000):

W. Myszor - Tysiąc lat panowania Chrystusa na ziemi. Millenaryzm w ujęciu Ireneusza z Lyonu ("Adversus haereses» V, 30,4-36, 3), 5-24; A. Uciecha Afrahat, mędrzec perski. Stan badań 25-40; R. Nakonieczny - „Exempla” Cycerońskie w «De officiis ministrorum» św. Ambrożego 41-56; W. Myszor - Pierwsza i druga Apokalipsa Jakuba z V Kodeksu z Nag Hammadi 57-76.

216. TARNOWSKIE STUDIA TEOLOGICZNE 19 (2000) nr 1-2:

K. Witko - Millenaryzm w pierwszych wiekach chrześcijaństwa 3-8; H. Pietras - Millenaryzm a interpretacja szabatu (I-II w.) 9-25; W. Myszor - Millenaryzm w ujęciu Ireneusza z Lyonu 27-38; M. Szram - Orygenes a millenaryzm 39-53; M.C. Paczkowski - Interpretacja millenarystyczna idei Jerozolimy (II-III wiek) 55-62; J. Wojtczak - Problem millenaryzmu 
w twórczości Laktancjusza 63-66; A. Żurek - Wykaz prac magisterskich napisanych $w$ Instytucie Teologicznym $w$ Tarnowie w roku 1999, 295-299.

217. TEOFIL 10 (2000) $\mathrm{nr}$ 2(13):

D. Dembińska - Platon a święty Augustyn (glosa) 138-144.

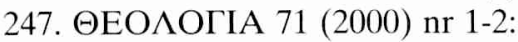

J.S. Romanides - Yahweh of glory according to the 1st, 2nd and 9th ecume-

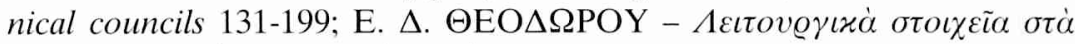

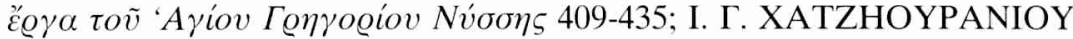

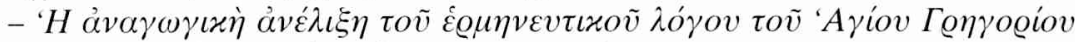

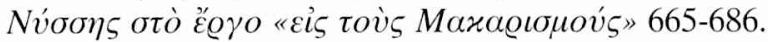

248. TEOLOGIA Y VIDA 41 (2000) nr 1-4:

R. Polanco Fermandois - El milenarismo de Ireneo o teología antignostica de la „caro capax Dei” 16-29; S. Fernández - Itinerario hacia Dios. Elementos de escatología origeniana 30-41; C. Pierantoni - El fin del mundo en San Agustín 42-51; S. Fernandez Eyzaguirre - La patrologia en los 40 años de Teología y Vida 310-327.

249. TERMINUS 2 (2000) z. 1-2:

H. Pietras - Aniołowie w teologii Ireneusza z Lyonu na tle tradycji judeochrześcijańskiej 51-72.

250. THEOLOGICAL STUDIES 61 (2000) nr 1-4:

F.G. McLeod - Theodore of Mopsuestia Revisited 447-480; G. Macy - The Ordination of Women in the Early Middle Ages 481-507.

251. THEOLOGIE UND PHILOSOPHIE 75 (2000) nr 1-4:

H.J. Sieben - Nomina Christi. Zur Tradition der Christustitel (2.-16. Jh.) 3058; E.M. Synek - Die Relevanz patristischer Forschung für die ökumenische Entwicklung der Gegenwart 74-88; A. Fürst - Laßt uns erwachsen werden! Ethische Aspekte der Eschatologie des Origenes 321-338.

252. THEOLOGISCHE QUARTALSCHRIFT 180 (2000) nr 1-4:

H.J. Vogt - Cyrill und das Credo von Konstantinopol (381), 25-29; H.J. Vogt - Vertreten die Ignatius-Briefe Patripassionismus? 237-251.

253. THEOLOGISCHE ZEITSCHRIFT 56 (2000) nr 1-4:

A.D. Baum - Der Presbyter des Papias über einen Hermeneuten des Petrus. Zu Eusebius, «Hist. eccl» III 39, 15, s. 21-35; W. von Meding - Zwei Thesen zur Trinitätslehre. Beobachtungen an der frühchristlichen und Luthers Konzeption 233-263.

254. THEOTOKOS 8 (2000) $\mathrm{nr} 1-2$ :

C. Corsato - Ap 12, 1-6: Riletture patristiche 67-84.

255. TOPOI 19 (2000) nr 1-2:

T.A. Druart - Philosophical Consolation in Christianity and Islam: Boethias and al-Kindi 25-34.

256. UNITÉ 35 (2000) nr 118-120:

(Nr 118) I.H. Dalmais - Les Églises du patriarcat d'Antioche 4-8; (Nr 120) 
J.N. Pérès - Une voie royale pour un peuple royal. Simples réflexions sur le Christ et les chrétiens selon les «Stromates» de Clément d'Alexandrie 22-25; A. Gila - Testi e simboli biblici riletti dai Padri in chiave mariana 601-631. 257. VERBO SPEIRO 39 (2000) nr 381-388:

J. Orlandis - Cristianismo e imperio romano pagano 537-549. 258. VETERA CHRISTIANORUM 37 (2000) nr 1-2:

A. Campione - Le diocesi paleocristiane lucane nelle fonti letterarie fino a Gregorio Magno 5-33; R. Infante - Maria di Betania e l'unzione di Gesù: Gv 12, 1-8, 35-55; A. Piras - Riflessioni cristologiche nella versione siriaca di un'omelia di Giovanni Crisostomo sull'Incarnazione 57-68; I. Ramelli - Alcune annotazioni sulle origini del cristianesimo in Gallia 69-86; S. Santelia - Nota ad ICUR II, 4785: echi di Prospero d' Aquitania? 87-92; D. Scortecci - La creazione dell' uomo psichico da parte dei Sette Arconti e degli Angeli 93-111; M. Simonetti-Origene e il pozzo di Giacobbe 113-126; C. Urso - La calunnia nella legislazione e nell'immaginario collettivo dei Franchi 127-155; R. Giuliani - I mosaici del complesso paleocristiano di Barletta 157-182; A. Di Fazio - Note sulla fortuna patristica di Prov 6, 11, 183-189; N. Adkin - Two Further Echoes of Sallust's «Histories» in Jerome («Vita Hilarionis» 22,3 and 30,2)? 209-215; M. Buonocore - Paganesimo o cristianesimo tra i Marci Annanei in Italia 217-234; E. Colombi Iuvenciana I, 235-269; P. De Navascués - De montibus Sina et Sion: judios, magos y mártires entre apocalíptica y donatismo 271-315; A.E. Felle - Note sui materiali laterizi della nuova Basilica Circiforme della via Ardeatina 317-336; A.E. Felle \& R. Giuliani - Nuove indagini nella catacomba dell'ex Vigna Chiaraviglio nel comprensorio callistiano dell' Appia Antica a Roma (1990-1991), 337-351; V. Fiocchi Nicolai - Ricerche sui monumenti paleocristiani del Lazio 353-390; L. Giordano - Gregorio Magno e il diritto d'asilo 391-406; A.V. Nazzaro - Filologia e deontologia. Ancora su Ambr. uid 1,3 e Paul. Nol. carm. 10,213, 407-412; F.M. Catarinella - Una ripresa agostiniana in Sidonio Apollinare (ep. II, 13,2) 413-418.

259. VIE CONSACRÉE 72 (2000) nr 1-6:

Soeur Marie-Ancilla - La règle de saint Augustin 184-203.

260. VIGILIAE CHRISTIANAE 54 (2000) nr 1-4:

E.P. Meijering - Irenäus zum zeitlichen Anfang der Welt 1-11; E. Osborn Love of Enemies and Recapitulation 12-31; H.E. Lona - Zur Struktur von Diog 5-6, 32-43; A.P. Bos - Basilides as an Aristotelianizing Gnostic 44-60; M. Laird - ,By Faith Alone”: A Technical Term in Gregory of Nyssa 61-79; V. Hunink - Apuleius, Pudentilla, and Christianity 80-94; J.A. Draper Ritual Process and Ritual Symbol in «Didache» 7-10, 121-158; M.J. Edwards - Clement of Alexandria and his Doctrine of the Logos 159-177; A. Canellis - Saint Jérôme et les passions: Sur les "Quattuor Perturbationes» des Tusculanes 178-203; G. Hays - A Second Look at Fulgentius's 
"Alexander» 204-207; A. Alcock - The Agape 208-209; E. Laupot - Tacitus' Fragment 2: The Anti-Roman Movement of the Christiani and the Nazoreans 233-247; D.J. Bingham - Justin and Isaiah 53, 248-261; R.A. Layton „Propatheia”: Origen and Didymus on the Origin of the Passions 262-282; J. Hofmann - Christliche Frauen im Dienst kleinasiatischer Gemeinden des ersten und zweiten Jahrhunderts. Eine prosopographische Studie 283-308; O. Nicholson - Constantine's Vision of the Cross 309-323; H.M. Knapp Melito's Use of Scipture in "Peri Pascha»: Second-Century Typology 343-374; N. Koltun-Fromm - Sexuality and Holiness: Semitic Christian and Jewish Conceptualizations of Sexual Behavior 375-395; M. Horsfall Scotti - The Asclepius: Thoughts on a Re-opened Debate 396-416; H. Seng - Aspekte metrischer Theorie im "Cathemerinon» des Prudentius 417-431.

261. VOX LATINA 36 (2000) nr 139-142:

Aurelius Augustinus - Homília natalicia, (Sermo 188, PL 38, 1003-1005), 470-471.

262. W DRODZE (2000) nr 1-12:

(Nr 1) W. Prus - Tęsknota i przyjaźń (1). Historia nawrócenia św. Augustyna z Hippony 30-44; J.S. - Na czym polegat bład papieża Honoriusza 103-111; (Nr 2) W. Prus - Tęsknota i przyjaźń (2) 43-53; (Nr 11) J.S. Czy święty Augustyn chodzit do spowiedzi 103-109.

263. WARSZAWSKIE STUDIA TEOLOGICZNE 12 (1999) nr 1-2:

E. Fritsch - The Liturgical Year and the Lectionary of the Ethiopian Church. Introduction to the Temporal 71-116; J. Krykowski - Alcuni aspetti della catechesi sulla preghiera in Tertulliano e in Cipriano 91-107; J. Miazek Misterium Chrystusa w liturgii Adwentu Sakramentarza Gelazjańskiego 145156; Augustyn, Kazanie o zniszczeniu miasta Rzymu, tłum. i oprac. Kazimierz Obrycki 157-170; M. Starowieyski - Komentarze biblijne patrystyczne $w$ "De viris illustribus» św. Hieronima 205-216; W. Witakowski - Theodoxia and her finding of the Holy Cross: An Ethiopic version of the Legend of the "Finding of the Holy Cross» in the "Miracules of Mary» 253-269.

264. THE WESTMINSTER THEOLOGICAL JOURNAL 62 (2000) nr 1-2: H. Knapp - Augustine and Owen on Perseverance 65-87.

265. ВЕСТНИК ДРЕВНЕЙ ИСТОРИИ (2000) nr 230-235:

(Nr 230) А. Б. Ванькова - Некоторые замечания о статусе монахов и монастьрей по сбетскому и церковному законодательству IV 8. 153-159.

266. WIADOMOŚCI DIECEZJI ŁOWICKIEJ 8 (2000) nr 1-5:

J. Krykowski - Pierwszy chrześcijański rok jubileuszowy (A. D. 1300) inspiracje biblijne i uwarunkowania historyczne 68-77.

268. ВОПРОСЫ ФИЛОСОФИИ (2000) nr 1-12:

(Nr 8) А. В. Ситников - Философия Плотина и патристика о происхождении космоса 117-125; Т. Ю. Бородай - Критика гности- 
цизма у Плотина 128-139; Плотин - Против гностиков (II, 9[33]) 14-154.

269. WORSHIP 74 (2000) nr 1-6:

M.S. Driscoll - S.G. Sheridan - Every Knee Shall Bend: A Biocultural Reconstruction of Liturgical and Ascetical Prayer in V-VII Century Palestine 453-468.

270. ZAGADNIENIA FILOZOFICZNE W NAUCE 1 (1999) nr 25-26:

(Nr 26) J. Dadaczyński - Akceptacja nieskończoności aktualnej u św. Augustyna 61-75.

271. ZEITSCHRIFT FÜR ANTIKES CHRISTENTUM 4 (2000) nr 1-2:

D. Weber - Zweiter Bericht über lateinische Editionen und Hilfsmittel aus dem Gebiet der Patristik 3-12; G. Baudy - Das Evangelium des Thamus und der Tod des , großen Pan”. Ein Zeugnis romfeindlicher Apokalyptik aus der Zeit des Kaiser Tiberius? 13-48; M. Vinzent - „Oxbridge” in der ausgehenden Spätantike oder: Ein Vergleich der Schulen von Athen und Alexandrien 49-82; J. Zachhuber - The Antiochene Synod of AD 363 and the Beginnigs of Neo-Nicenism 83-101; K.M. Girardet - „Renovatio imperii” aus dem Geiste des Christentums. Zu Herkunft und Umfeld des Begriffs 102-115; K.L. Noethlichs - „Quid possit antiquitas nostris legibus abrogare"? Politische Propaganda und praktische Politik bei Justinian I. im Lichte der kaiserlichen Gesetgebung und der antiken Historiographie 116-132; H.Ch. Brennecke - ,Imitatio - reparatio - continuatio”. Die Judengesetzgebung im Ostgotenreich Theoderichs des Großen als „reparatio imperii” 133-148; R.E. Heine - Evidence for the Date of Origens Commentary on Ephesians 149-157; M. Wallraff - Patristische Arbeitshilfen im Internet (III). Forschungsprojekte und -gruppen 158-160; F. Mitthof - Bruchstück einer Homilie des Amphilochios von Ikonion aus frühbyzantinischer Zeit (Or. VI 1-3), 209-216; H. Nemo - Letter to Keith Hopkins 219-224; Ch. Markschies - New Research on Ptolemaeus Gnosticus 225-254; V. Leppin - Das Bischofsmartyrium als Stellvertretung bei Cyprian von Karthago 225-269; A. Fürst - Die Selbsterkenntnis des Skeptikers im "Octavius» des Minucius Felix 270-281; T.D. Barnes - Ambrose and the Basilicas of Milan in 385 and 386: The Primary Documents and their Implications 282-299; S. Rebenich - Vom dreizehnten Gott zum dreizehnten Apostel? Der tote Kaiser in der Spätantike 300-324; R. Schneider - Vorund Frühformen einer "Renovatio Imperii” in christlichen Germanenreichen der Völkerwanderungszeit 325-337; M. Jenks - „Romanitas” and "Christianitas” in the Coinage of Theodebert I of Metz 338-368; G.Ch. Hansen - Was darf ein Editor? 369-374.

272. ZEITSCHRIFT FÜR KATHOLISCHE THEOLOGIE 122 (2000) nr 1-2: G. Podskalsky - Tod und Auferstehung in der byzantinischen Theologie 14-33. 
273. ZESZYTY MARYJNE 3 (2000) nr 1-5:

(Nr 1) Ojciec Bruno - Świadectwo Ojców. Wstuchany w milczenie Boga 1820; (Nr 2) Ojciec Bruno - Zachwycony Bożym duchem zbawienia 18-20; (Nr 3) Ojciec Bruno - Obrońca Dziewicy Maryi 16-18; (Nr 4) Ojciec Bruno - Rola Maryi w historii zbawienia 14-15; (Nr 5) Ojciec Bruno - Obrońca dziewiczego poczecia Jezusa 14-15.

274. ZIEMIA ŚWIĘTA 6 (2000) nr 1-4:

(Nr 2) J. Janicki - Egeria - «Pielgrzymka do miejsc świętych». Wielki Post w IV wieku 28-29; ( $\mathrm{Nr} 4)$ J. Janicki - Egeria - «Pielgrzymka do miejsc świętych». Liturgia w IV wieku 52-54.

275. ZNAK 52 (2000) nr 536-547:

(Nr 537) M. Borkowska - Sylwetki Ojców Pustyni. Pambo: poważna łagodność 113-117; (Nr 539) M. Borkowska - Sylwetki Ojców Pustyni. Żywy przykład Makarego 105-109; (Nr 546) J. Kracik - Męczennicy od czcicieli zależni 46-60;

276. Z OTCHŁANI WIEKÓW 55 (2000) nr 1-4:

(Nr 1) R. Głowacki - Chleba naszego powszedniego... czyli o kulinarnych aspektach życia pierwszych mnichów 65-74; (Nr 2) U. Perlikowska-Puszkarska - Wystawa „W górę Nilu, w głąb czasu” w Państwowym Muzeum Archeologicznym w Warszawie 65-71; (Nr 3-4) R. Głowacki - Mitologia wczesnego chrześcijaństwa 100-106; K. Stanek - Leptis Magna: perta starożytnej Afryki 145-149.

277. ŻYCIE DUCHOWE 7 (2000) nr 21-24:

(Nr 21) D. Kowalczyk - Księża mówiq kazania, czyli triumf heretyka Pelagiusza 67-77; ( $\mathrm{Nr} 23$ ) Jestem od uczenia tolerancji. Rozmowa z profesor Ewą Wipszycką, (rozmawia S. Obirek SJ) 6-15.

zebrał ks. Józef Figiel 